\title{
KARAKTERISASI RESERVOIR KARBONAT BERDASARKAN ANALISIS INVERSI SEISMIK IMPEDANSI AKUSTIK DAN ATRIBUT SEISMIK DI LAPANGAN "CLM" CEKUNGAN JAWA BARAT UTARA
}

\author{
ABDUL HAKIM PRIMA YUNIARTO* \\ Program Studi Fisika, Institut Teknologi dan Sains Nahdlatul Ulama Pekalongan \\ Jl. Karangdowo No.9 Kec.Kedungwuni, Kab. Pekalongan 51173 \\ *email : a.hakim.py@gmail.com
}

\begin{abstract}
Abstrak. Penelitian dengan data 2D seismik dan sumur yang digunakan untuk analisis inversi seismik impedansi akustik (IA) dan analisis atribut seismik telah dilakukan di Lapangan "CLM" Cekungan Jawa Barat Utara. Tujuan dari penelitian ini adalah untuk memperoleh pola persebaran impedansi akustik pada reservoir karbonat dan menentukan zona prospek hidrokarbon pada daerah penelitian. Pola distribusi impedansi akustik diperoleh dengan proses inversi IA dilakukan pada 15 lintasan seismik 2D post-stack dan 2 sumur. Sedangkan identifikasi zona prospek hidrokarbon dilakukan dengan mengintegrasikan 3 peta yaitu peta slice impedansi akustik, peta slice atribut RMS amplitude dan peta slice atribut envelope. Berdasarkan hasil dari inversi seismik impedansi akustik diperoleh zona target reservoir pada Formasi Cibulakan Atas yaitu karbonat memiliki nilai AI tinggi dengan rentang sebesar 42.500-52.500 (ft/s)(g/cc). Sandstone memiliki nilai AI sedang dengan rentang sebesar 34.000-42.500 (ft/s) $(\mathrm{g} / \mathrm{cc})$ dan shale memiliki nilai AI rendah dengan rentang sebesar 21.000-34.000 (ft/s)(g/cc) yang berpotensi menjadi batuan tudung (seal). Sedangkan berdasarkan hasil dari analisis atribut seismik diperoleh zona prospek hidrokarbon berada pada sebelah timur laut dan barat laut dari lokasi sumur ITSNU-2 di lapangan "CLM" daerah penelitian.
\end{abstract}

Kata kunci: atribut seismik; cekungan jawa barat utara; impedansi akustik; inversi seismik; karakterisasi reservoir

\begin{abstract}
Research with 2D seismic data and wells used for acoustic impedance (AI) seismic inversion analysis and seismic attribute analysis has been carried out in the "CLM" Field of the North West Java Basin. The purpose of this study is to obtain the distribution pattern of acoustic impedance in the carbonate reservoir and to determine the hydrocarbon prospect zone in the study area. The acoustic impedance distribution pattern is obtained by the AI inversion process carried out on $152 \mathrm{D}$ post-stack seismic lines and 2 wells. Meanwhile, the identification of hydrocarbon prospect zones is carried out by integrating 3 maps, namely acoustic impedance slice maps, RMS amplitude attribute slice maps and envelope attribute slice maps. Based on the results of the acoustic impedance seismic inversion, it was found that the target reservoir zone in the Upper Cibulakan Formation was carbonate that had high AI values with a range of 42500-52500 (ft/s) $(\mathrm{g} / \mathrm{cc})$. Sandstone has a moderate AI value with a range of 34000-42500 (ft/s)(g/cc) and shale has a low AI value with a range of $21000-34000(\mathrm{ft} / \mathrm{s})(\mathrm{g} / \mathrm{cc})$ which has the potential to become a seal rock. Meanwhile, based on the results of the analysis of seismic attributes, the hydrocarbon prospect zone is located in the northeast and northwest of the ITSNU-2 well location in the "CLM" field in the research area.
\end{abstract}

Keywords: acoustic impedance; northwest java basin; reservoir characterization; seismic attribute; seismic inversion 


\section{Pendahuluan}

Salah satu daerah yang menghasilkan hidrokarbon di Indonesia yaitu Cekungan Jawa Barat Utara. Pada Cekungan Jawa Barat Utara terindikasi adanya cadangan hidrokarbon yang cukup banyak, terutama pada wilayah lapangan "CLM" [1]. Lapangan "CLM" masih perlu dilakukan pengembangan yaitu dengan evaluasi stratigrafi dan struktur geologinya. salah satunya yaitu mengkarakterisasi reservoir yang terdapat di formasi Cibulakan Atas. Formasi Cibulakan Atas merupakan termasuk dalam lingkungan pengendapan untuk reservoir karbonat terumbu yang sangat baik [2]. Eksplorasi hidrokarbon semakin kesini semakin kompleks, maka untuk mengembangan lapangan minyak bumi diperlukan suatu metode yang lebih efektif dan akurat, salah satunya adalah metode inversi seismik.

Inversi seismik adalah metode seismik yang bertujuan untuk menggambarkan kondisi geologi di bawah permukaan dengan masukan berupa data seismik yang kemudian dikontrol oleh data sumur [3]. Salah satu metode inversi seismik adalah inversi impedansi akustik (IA) yang merupakan parameter yang menggambarkan porositas dan litologi batuan [4]. Oleh karena itu IA digunakan untuk mengetahui karakteristik dari suatu reservoir hidrokarbon.

Pada penelitian ini selain menggunakan parameter nilai impedansi akustik (IA) juga menggunakan parameter atribut seismik, sehingga dapat mengkarakterisasi reservoir dengan lebih akurat. Atribut seismik dapat memberikan tampilan yang berbeda dari data seismik biasa namun dengan skala yang sama, sehingga dapat memberikan informasi tambahan dari data seismik biasa [5].

Penelitian menggunakan integrasi metode inversi seismik dan atribut seismik telah berhasil mengkarakterisasi reservoir karbonat di Cekungan Jawa Timur Utara oleh [6]. Interpretasi persebaran karbonat di Formasi Cibulakan Atas dengan menggunakan integrasi antara metode inversi seismik dengan atribut seismik telah berhasil dilakukan oleh [7]. Metode inversi seismik juga dilakukan oleh [8] untuk mengkarakterisasi reservoir di Cekungan Sumatera Utara. Kemudian [9] juga telah berhasil mengidentifikasi reservoir di perairan Nias menggunakan inversi impedansi akustik.

Berdasarkan uraian di atas maka diperlukan karakterisasi reservoir di lapangan "CLM" dengan memanfaatkan atribut seismik dan metode inversi seismik impedansi akustik. Acoustic Impedance (AI) atau impedansi akustik adalah sifat batuan yang diturunkan dari perkalian antara kecepatan gelombang seismik (Vp) dan densitas batuan $(\rho)$ seperti yang ditunjukkan pada Persamaan 1.

$$
A I=V_{P} \rho
$$

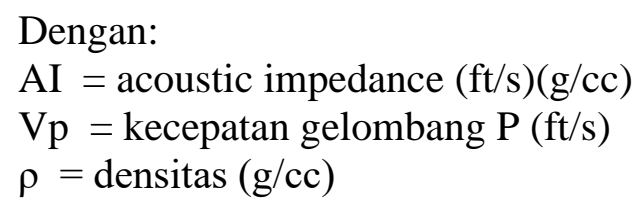

Impedansi akustik (IA) dapat diibaratkan dengan acoustic hardness. Batugamping dan granit yang keras dan sulit untuk dimampatkan mempunyai nilai impedansi akustik yang tinggi, sedangkan batuan lempung yang lunak dan mudah untuk dimampatkan mempunyai nilai impedansi akustik yang rendah [4]. Berdasarkan penampang IA dapat menggambarkan kondisi geologi yang berada di bawah permukaan dengan lebih detail jika dibandingkan dengan penampang seismik biasa. 
Impedansi akustik bisa memberikan gambaran batas lapisan dan juga sebagai indikator porositas, litologi dan keberadaan cadangan hidrokarbon, sehingga dapat digunakan untuk deskripsi karakteristik reservoir [9].

Atribut seismik merupakan tampilan yang menggambarkan data seismik secara deskriptif dan kuantitatif dengan skala yang sama dari data seismik awal. Atribut seismik dapat didefinisikan sebagai pengukuran dinamika, kinematika dan analisis statistik yang diturunkan secara spesifik dari data seismik [5].

Penerapan seismik atribut yaitu dengan menurunkan gelombang seismik konvensional dengan manipulasi matematis menjadi fungsi tertentu, sehingga diperoleh informasi yang berguna dalam proses interpretasi bawah permukaan. Informasi yang paling penting dari atribut seismik yaitu amplitudo, waktu, atenuasi dan frekuensi [5]. Semua penampang dan bentuk dari atribut-atribut tersebut saling berhubungan satu dengan yang lainnya, yang jadi pembeda adalah pada analisis data informasi dasar yang mempengaruhi gelombang seismik dan hasil yang ditampilkan.

Umur sedimentasi di Cekungan Jawa Barat Utara yaitu dalam kisaran Eosen Tengah hingga zaman Quarter. Endapan yang tertua berumur Eosen Tengah, yaitu Formasi Jatibarang yang mengendap diatas batuan dasar secara tidak selaras, sedangkan endapan yang termuda berumur Pleistosen yaitu Formasi Cisubuh. Susunan urutan stratigrafi dari yang termuda hingga yang tertua yaitu Formasi Cisubuh, Formasi Parigi, Formasi Cibulakan Atas, Formasi Cibulakan Bawah (Formasi Talang Akar, Formasi Baturaja), Formasi Jatibarang dan Formasi Cisubuh [10].

Petroleum system pada Cekungan Jawa Barat Utara terdiri atas batuan induk (source rock), batuan penyimpan (reservoir), tipe jebakan (trap), jalur migrasi (proper timing of migration) dan lapisan tudung (seal), seperti ditunjukkan pada Gambar 1.

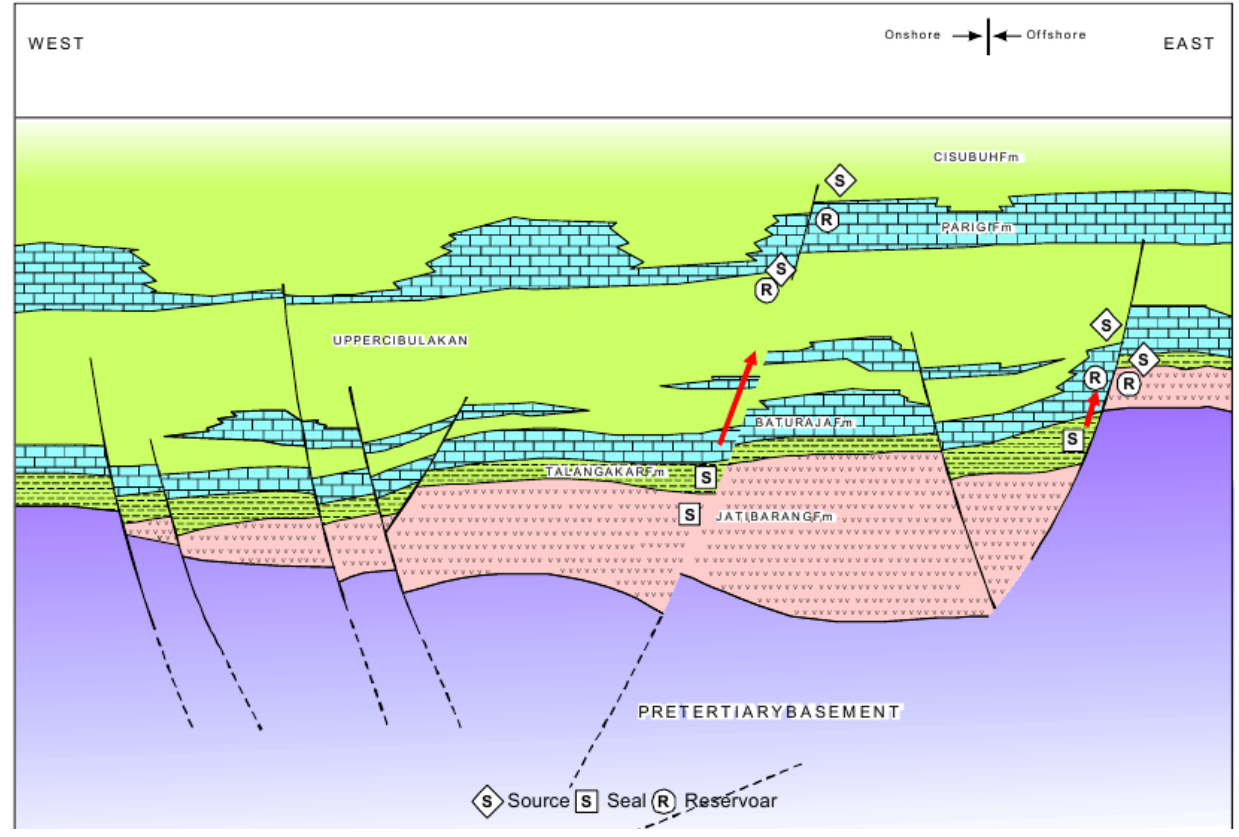

Gambar 1. Petroleum System Cekungan Jawa Barat Utara [10] 


\section{Metode Penelitian}

Penelitian dilakukan di Lapangan "CLM" pada wilayah Cekungan Jawa Barat Utara, seperti yang ditunjukkan pada Gambar 2. Penelitian ini menggunakan data sumur dan data seismik. Data seismik yang digunakan merupakan data seismik 2D Post Stack Time Migration, dengan jumlah sebanyak 15 lintasan yang diperoleh dari Pertamina Daerah Operasi Hulu (DOH) Jawa Bagian Barat. Sedangkan data sumur yang digunakan terdapat 2 data sumur yaitu sumur ITSNU-1 dan ITSNU-2. Data sumur terdiri atas log density, log sonic, log gamma-ray, log caliper, log induction, log neutron porosity, log self potensial (SP) dan checkshot. Data sumur digunakan dalam sebagian besar tahapan pengolahan seperti well-seismic tie, pembuatan initial model dan analisis inversi. Gambar 3 menunjukkan base map dari data seismik dan data sumur dalam penelitian ini.

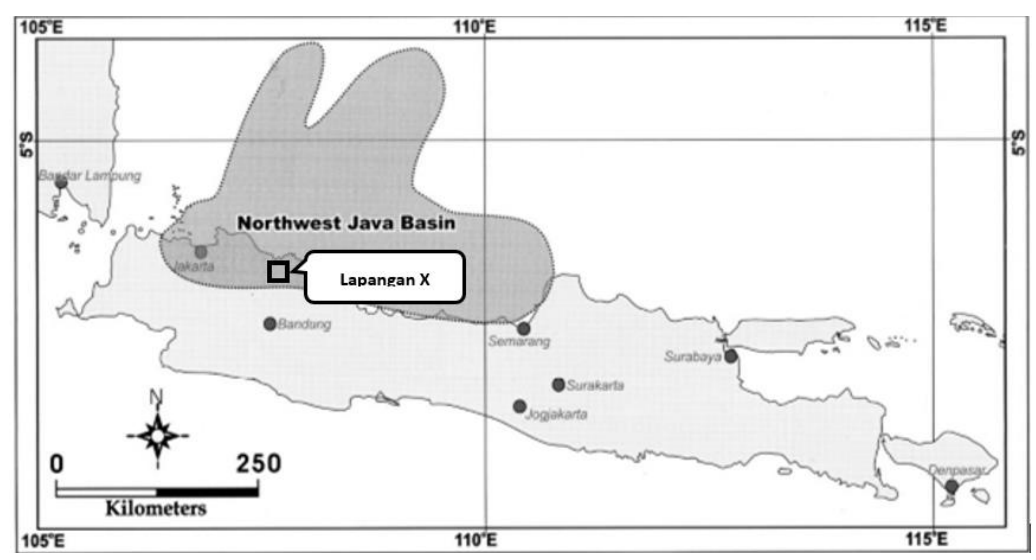

Gambar 2. Cekungan Jawa Barat Utara [11]

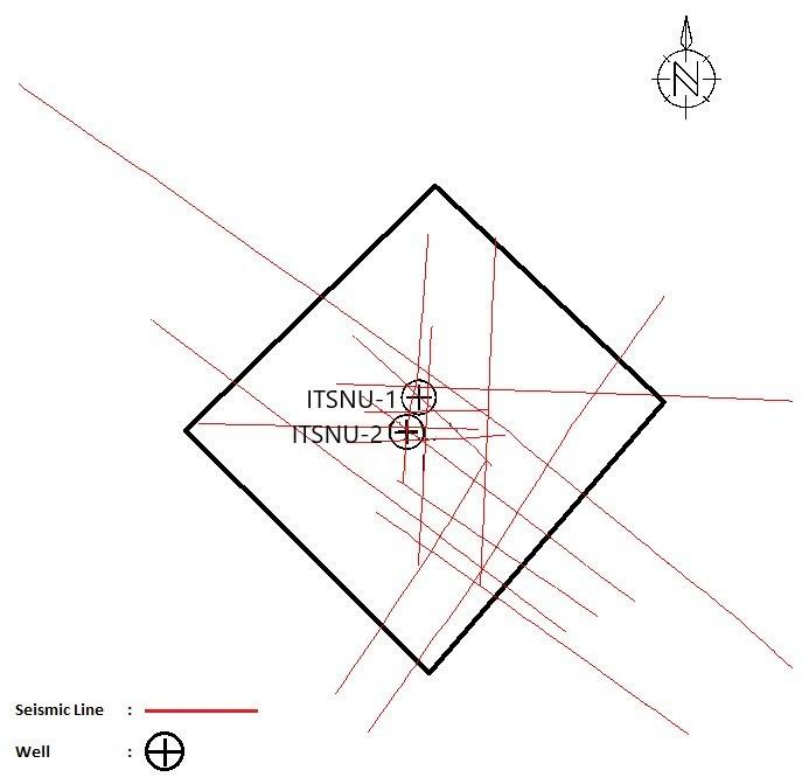

Gambar 3. Base map area penelitian

Pengolahan data dimulai dengan analisis zona target menggunakan data log dan marker pada data sumur. Pada analisis zona target juga dilakukan korelasi struktur 
dan stratigrafi dengan menggunakan data kedua sumur yaitu ITSNU-1 dan ITSNU2. Selanjutnya dilakukan analisis crossplot menggunakan parameter P-Impedance, density dan neutron porosity untuk memisahkan zona target berdasarkan parameter yang digunakan dan menjadi acuan kelayakan untuk dilakukan inversi.

Kemudian melakukan well seismic tie pada kedua sumur tersebut untuk menyamakan data sumur yang berdomain kedalaman dengan data seimik yang berdomain waktu atau membawa resolusi seismik yang kecil secara vertikal ke resolusi data sumur yang tinggi secara vertikal menggunakan seismogram sintetik dan checkshot. Proses well seismic tie menghasilkan berupa nilai amplitudo seismik (checkshot terkoreksi) dengan kedalaman dan waktu yang sudah terintegrasi. Kemudian melakukan picking fault dan hasil picking fault digunakan sebagai acuan picking horizon. Hasil picking horizon tersebut digunakan untuk membuat peta time structure. Kemudian hasil amplitudo seismik tersebut digunakan untuk membuat atribut RMS amplitude dan atribut envelope. Pada proses selanjutnya hasil atribut seismik tersebut digunakan untuk interpretasi berupa peta slice map.

Tahapan selanjutnya yaitu inversi impedansi akustik (IA). Hasil dari inversi IA didapatkan volume inversi IA yang digunakan untuk membuat slice IA. Kemudian memasuki tahap interpretasi dengan korelasi peta slice IA, slice atribut RMS amplitudo, slice atribut envelope serta didukung informasi dari data geologi daerah penelitian untuk mendapatkan karakteristik dari reservoir dan zona prospek hidrokarbon pada lapangan penelitian.

\section{Hasil dan Pembahasan}

Pada data sumur dilakukan analisis zona target untuk melihat respon log pada Formasi Cibulakan Atas. Setelah itu dibuat crossplot log P-impedance versus log density dengan color key neutron porosity seperti ditunjukkan pada Gambar 4. Berdasarkan informasi dari well report bahwa reservoir karbonat yang menjadi target mempunyai porositas $8-14 \%$. Sehingga dari informasi tersebut dapat ditentukan cut-off dari nilai impedansi akustik pada target. Berdasarkan hasil crossplot dibagi menjadi 3 zona, yaitu carbonate, sandstone dan shale. Zona carbonate mengandung nilai impedansi tinggi dengan range 42.500-52.500 (ft/s)(gr/cc), sandstone mengandung nilai impedansi sedang dengan range 34.000$42.500(\mathrm{ft} / \mathrm{s})(\mathrm{gr} / \mathrm{cc})$, dan zona shale mengandung nilai impedansi rendah dengan range $21.000-34.000(\mathrm{ft} / \mathrm{s})(\mathrm{gr} / \mathrm{cc})$. Lapisan karbonat mempunyai nilai impedansi lebih besar daripada lapisan yang lainnya (warna biru), karena lapisan karbonat bersifat lebih kompak daripada lapisan yang lain. Lapisan karbonat ini juga mempunyai nilai porosity yang rendah, hal ini sesuai dengan informasi dari well report. Sehingga lapisan karbonat tersebut berpotensi sebagai reservoir pada Formasi Cibulakan Atas. Lapisan shale mempunyai nilai impedansi akustik yang relatif rendah (warna hijau). Lapisan shale ini diinterpretasikan sebagai lapisan tudung (cap rock) dari Formasi Cibulakan Atas. Sedangkan lapisan sandstone mempunyai nilai impedansi yang relatif sedang (warna kuning). Tetapi lapisan sandstone ini tidak berpotensi sebagai reservoir pada Formasi Cibulakan Atas. 


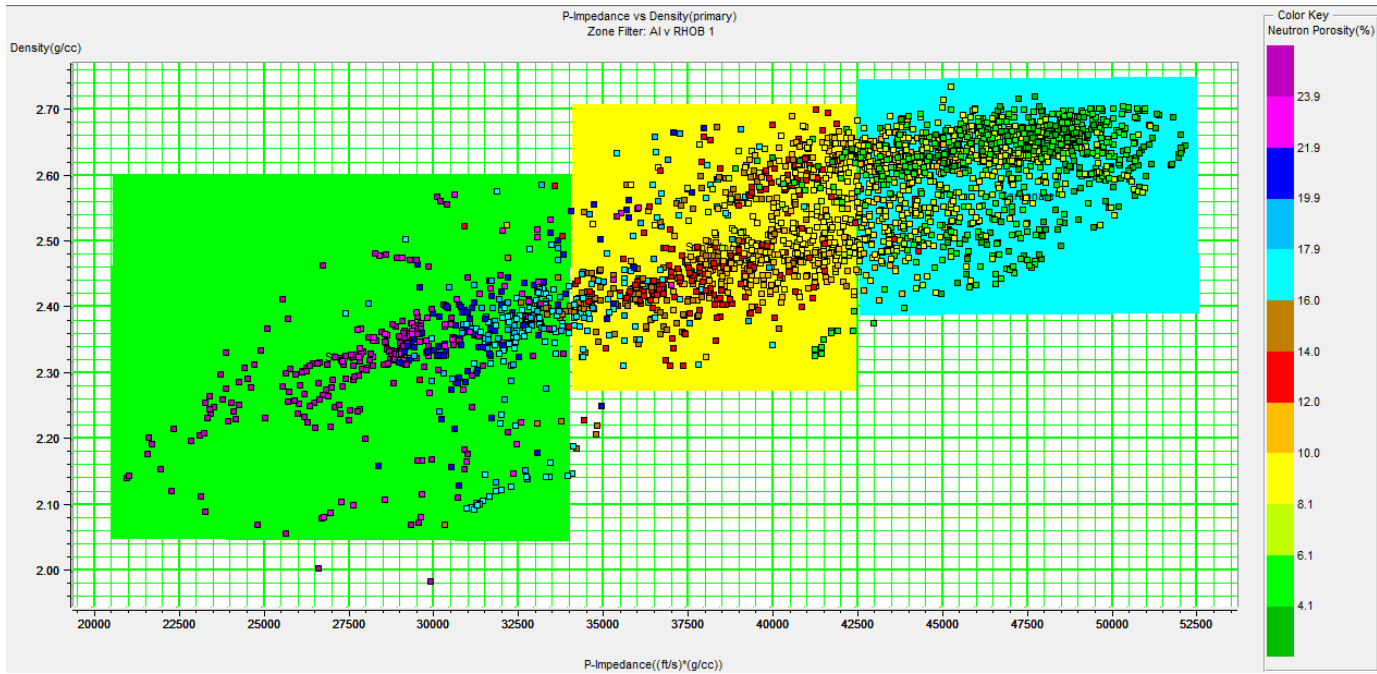

(a)

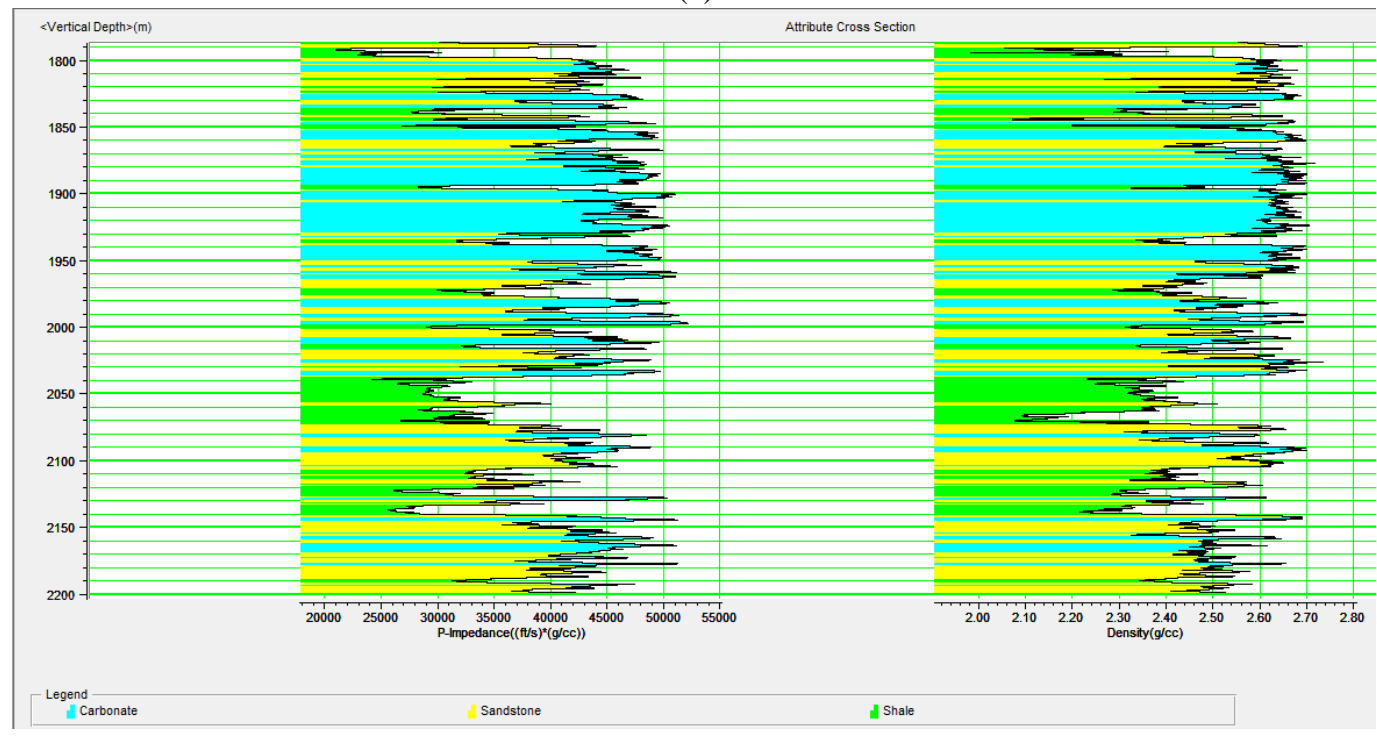

(b)

Gambar 4. Analisis crossplot p-impedance vs density (a) beserta cross-section AI dan density pada sumur ITSNU-1 (b)

Berdasarkan penampang hasil inversi pada Formasi Cibulakan Atas yang ditunjukkan Gambar 5, lapisan sandstone (warna kuning) berada pada bagian bawah formasi dengan sisipan-sisipan batuan karbonat (warna merah) yang tidak merata pada seluruh formasi. Kemudian pada bagian atas formasi tersusun oleh shale atau batu serpih (warna hijau). Jadi pada Formasi Cibulakan Atas ini berpotensi sebagai reservoir yang baik karena terdapat batuan karbonat sebagai batuan reservoir dan lapisan shale sebagai batuan penudung (seal) di bagian atas formasi.

Pada analisis penentuan zona prospek menggunakan integrasi dari 3 peta yaitu slice IA, slice atribut root mean square (RMS) amplitudo dan slice atribut envelope. Penentuan kedalaman slicing pada zona target menggunakan marker pada lapisan horizon Z-16. Masing-masing slice berasal dari hasil inversi AI, atribut RMS amplitudo dan atribut envelope. Kemudian hasil slicing pada masing-masing peta 
dilakukan overlay terhadap time structure maps pada horizon Z-16 agar diperoleh hasil yang lebih akurat.

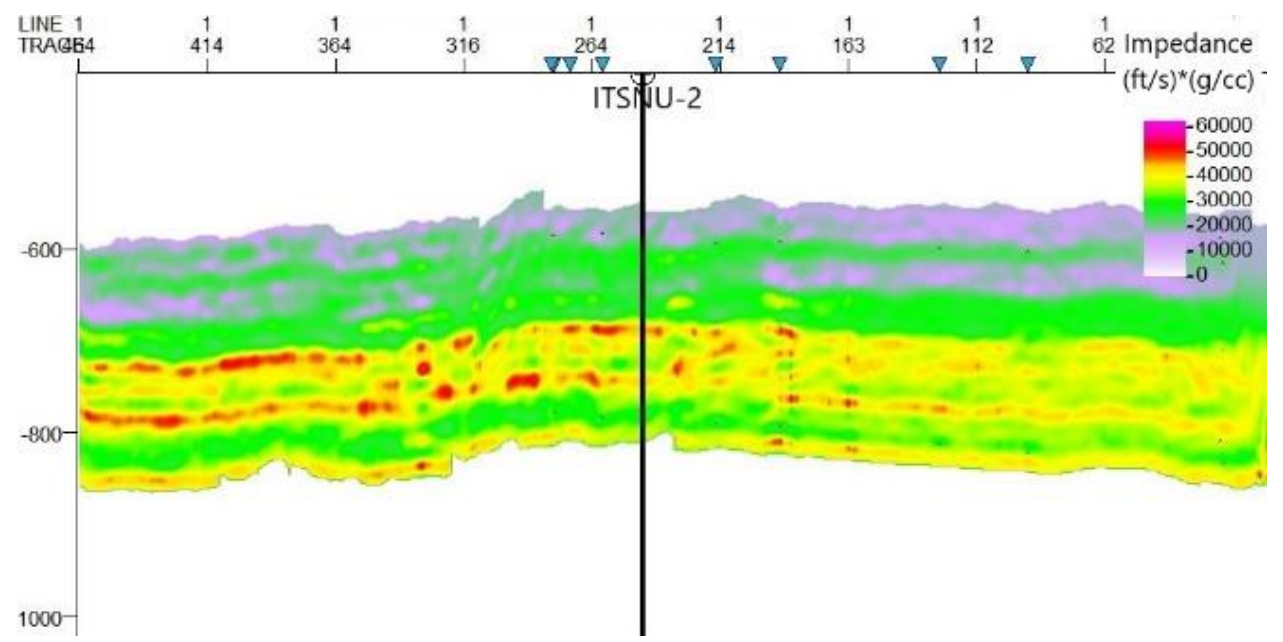

Gambar 5. Hasil inversi IA lintasan FISIKA-15

Menurut [6] keberadaan reservoir karbonat ditandai dengan nilai IA yang tinggi. Hasil slicing IA pada horizon Z-16 menunjukkan persebaran nilai P-Impedance (IA) karbonat berkisar antara 42.500-52.500 (ft/s)(g/cc) yang ditunjukkan dengan gradasi warna kuning-merah. Sedangkan lingkaran berwarna merah diinterpretasikan sebagai zona prospek hidrokarbon. Seperti ditunjukkan pada Gambar 6.

\section{Acoustic Impedance Map}

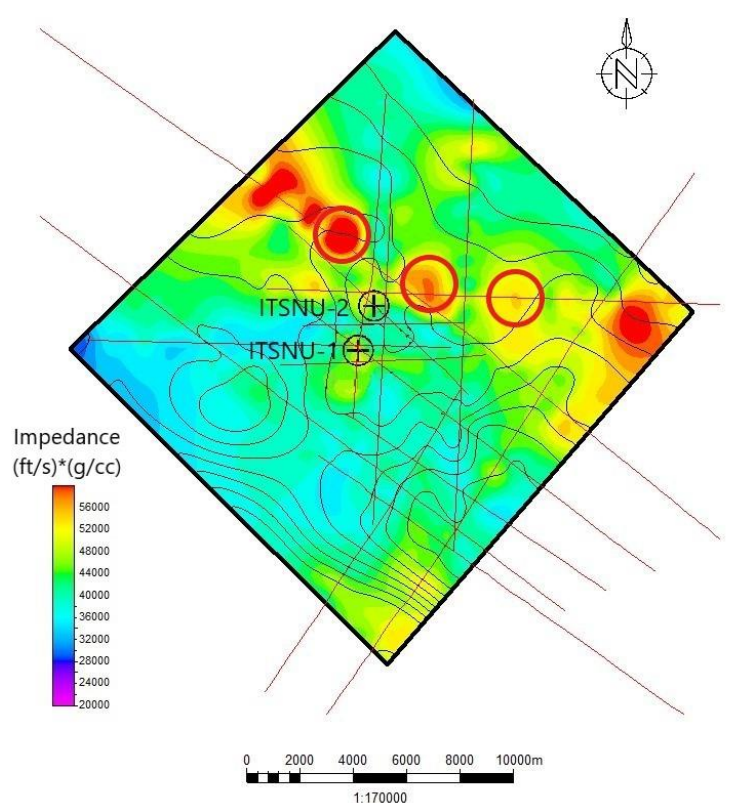

Gambar 6. Slice Acoustic Impedance dengan overlay kontur time structure horizon Z-16 
Amplitudo RMS dapat menggambarkan penyebaran lapisan reservoir. Keberadaan reservoir ditandai dengan nilai $R M S$ amplitudo yang tinggi [6]. Hal tersebut disebabkan karena terdapat kontras antara zona reservoir dengan litologi disekitarnya [12]. Hasil slicing atribut RMS amplitudo pada horizon Z-16 menunjukkan persebaran reservoir karbonat pada lapangan penelitian dengan kontras nilai $R M S$ amplitudo tinggi antara 25-30 yang ditunjukkan dengan gradasi warna kuning-merah. Sedangkan lingkaran berwarna merah diinterpretasikan sebagai zona prospek hirdrokarbon, seperti yang ditunjukkan pada Gambar 7.

\section{RMS Amplitude Map}

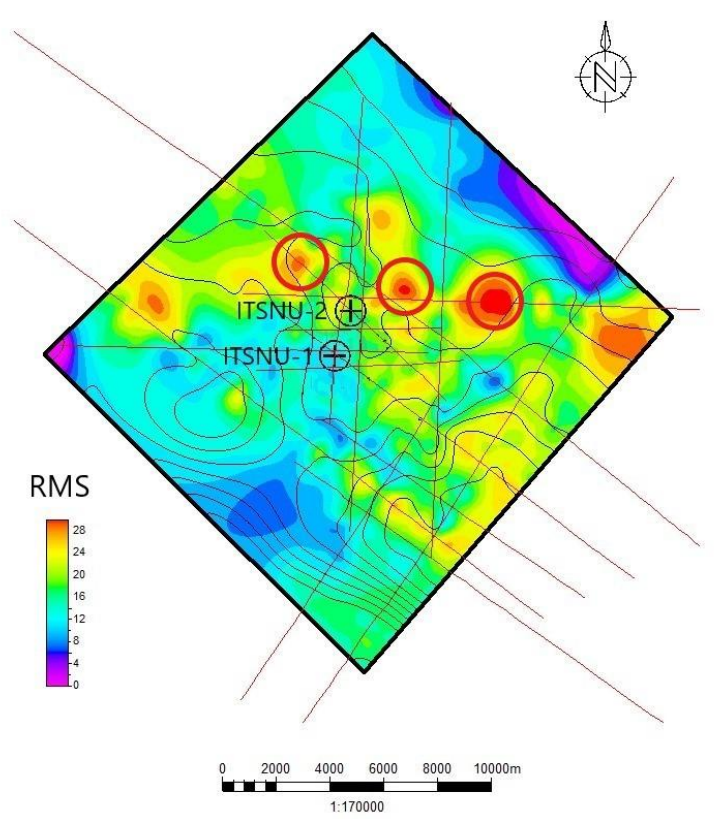

Gambar 7. Slice atribut RMS amplitudo dioverlay kontur time structure pada horizon Z-16

Atribut envelope dapat menggambarkan perbedaan litologi [12]. Atribut ini sensitif terhadap perubahan amplitudo secara lateral yang berasosiasi dengan perubahan karakteristik lapisan yang terakumulasi hidrokarbon. Menurut [7] keberadaan reservoir karbonat ditandai dengan nilai high envelope, karena adanya batas litologi yang signifikan. Hasil slicing envelope pada horizon Z-16 menunjukkan persebaran reservoir karbonat pada lapangan penelitian dengan kontras nilai envelope tinggi antara 30-40 yang ditunjukkan dengan gradasi warna kuning-merah. Sedangkan lingkaran berwarna merah diinterpretasikan sebagai zona prospek hidrokarbon, seperti yang ditunjukkan pada Gambar 8 .

Berdasarkan hasil slicing dari impedansi akustik, atribut $R M S$ amplitudo dan atribut envelope pada horizon Z-16 maka diperoleh 3 zona prospek yang ditandai dengan lingkaran berwana merah. Zona prospek tersebut berada pada sebelah timur laut dan barat laut dari lokasi sumur ITSNU-2 di lapangan "CLM" Cekungan Jawa Barat Utara. 


\section{Envelope Map}

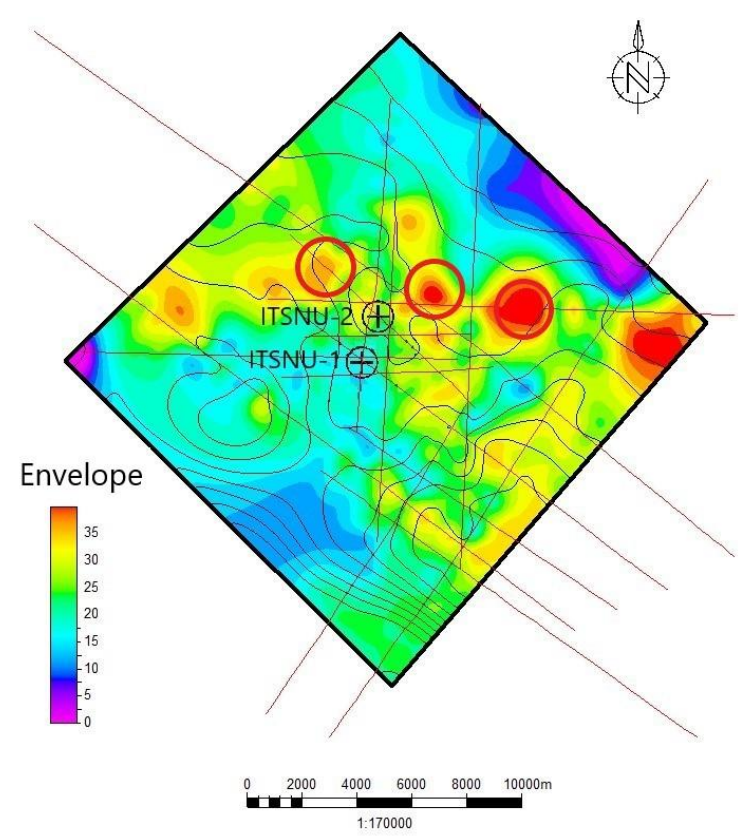

Gambar 8. Slice atribut envelope dengan overlay kontur time structure pada horizon Z-16

\section{Kesimpulan}

Zona target reservoir pada Formasi Cibulakan Atas yaitu karbonat memiliki nilai IA tinggi dengan range sebesar 42.500-52.500 (ft/s)(g/cc). Sandstone memiliki nilai IA sedang dengan range $34.000-42.500(\mathrm{ft} / \mathrm{s})(\mathrm{g} / \mathrm{cc})$ dan shale memiliki nilai IA rendah dengan range 21.000-34.000 (ft/s)(g/cc) berpotensi menjadi batuan tudung (seal). Sedangkan untuk zona prospek tersebut berada pada sebelah timur laut dan barat laut dari lokasi sumur ITSNU-2 di lapangan "CLM" daerah penelitian.

\section{Daftar Pustaka}

1. C. Reminton och U. Pranyoto, "A Hydrocarbon Generation Analysis in Northwest Java Basin using Lopatin's Method," i Proceeding IPA 14th Annual Convension, Jakarta, 1985.

2. C. Reminton och H. Nasir, "Potensial Hidrokarbon Pada Batuan Karbonat Miosen Jawa Barat Utara," i PIT IAGI XV, Yogyakarta, 1986.

3. B. Russell, Introduction To Seismic Inversion Methods, Third Edition, Volume 2, Domenico: Editor Course Notes Series, 1991.

4. S. Sukmono, Seismik Inversi untuk Karakterisasi Reservoir, Bandung: Penerbit ITB, 2000.

5. S. Chopra och K. Marfurt, Seismic Attributes for Prospect Identification and Reservoir Characterization, Tulsa: Society of Exploration Geophysicists, 2007.

6. R. Alifudin, W. Lestari, F. Syaifuddin och M. Haidar, "Karakterisasi Reservoir Karbonat dengan Aplikasi Seismik Atribut dan Inversi Seismik Impedansi Akustik," Jurnal Geosaintek, vol. 02, nr 02, 2016. 
7. D. Pramudito, T. Meidiana, A. Alfianto och D. Nurhadi, "How to Build New Interpretation Concept using Dynamic Data: A case Study in Carbonate of Upper Cibulakan, North West Java Basin, Indonesia," i IOP Conf. Ser. : Earth Environ, 2017.

8. M. S. Rosid, A. F. Thanniza och A. A. Andri, "Karakterisasi Reservoir Batuan Serpih Menggunakan Simultaneous Inversion di Lapangan TAF, Formasi Baong Bawah, Cekungan Sumatra Utara," Jurnal Fisika Unnes, vol. 9, nr 2, pp. 69-79, 2019.

9. M. Erryansah, T. Nainggolan och H. Manik, "Acoustic Impedance ModelBased Inversion to Identify Target Reservoir: a Case Study Nias Waters," i IOP Conf. Series: Earth and Environmental Science, 2020.

10. D. Arpandi och S. Patmosukismo, "The Cibulakan Formation as One of The Most Prospective Stratigraphic Units in The Northwestjava Basinal Area," i Proceeding IPA 4th Annual Convention, Jakarta, 1975.

11. Indonesian Basin Summaries, North West Java Basin, Jakarta: PT. Patra Nusa Data, 2006.

12. N. Alridha och S. Muhsin, "3-D Seismic Attributes Analysis in Balad Oil Field, Center of Iraq," Arab J Geosci, vol. 8, pp. 2785-2798, 2015. 